$12-2009$

\title{
Phylogeography and Postglacial Dispersal of Smallmouth Bass (Micropterus dolomieu) into the Great Lakes
}

\author{
W. Calvin Borden \\ Cleveland State University \\ Robert A. Krebs \\ Cleveland State University, r.krebs@csuohio.edu
}

Follow this and additional works at: https://engagedscholarship.csuohio.edu/scibges_facpub

Part of the Biology Commons

How does access to this work benefit you? Let us know!

Publisher's Statement

As of 2009, copyright of all articles in NRC Research Press journals remains with the authors.

\section{Recommended Citation}

Borden WC and Krebs RA. 2009. Phylogeography and postglacial dispersal of smallmouth bass (micropterus dolomieu) into the great lakes. Can J Fish Aquat Sci 66(12):2142-56.

This Article is brought to you for free and open access by the Biological, Geological, and Environmental Sciences Department at EngagedScholarship@CSU. It has been accepted for inclusion in Biological, Geological, and Environmental Faculty Publications by an authorized administrator of EngagedScholarship@CSU. For more information, please contact library.es@csuohio.edu. 


\title{
Phylogeography and postglacial dispersal of smallmouth bass (Micropterus dolomieu) into the Great Lakes
}

\author{
W. Calvin Borden and Robert A. Krebs
}

\begin{abstract}
Refugia and dispersal routes of smallmouth bass (Micropterus dolomieu) into the Great Lakes were identified using 427 mitochondrial sequences from across their native range. Overall, smallmouth bass accessed the Great Lakes via long-distance dispersal from multiple refugia, and the distribution of genetic variation reflected the consequences of vicariant, dispersal, and paleogeological events. Proximity of lakes to glacial outlets had a greater predictive power on the resulting distribution of mitochondrial diversity relative to interbasin migration. Populations in the Eastern and Interior Highlands contained the most divergent and oldest haplotypes, reflecting their role as glacial refugia and subsequent high incidence of endemicity. Lake Superior, Lake Michigan, and northern Lake Huron were colonized by bass of a single mitochondrial clade that accessed the Brule-Portage (Mississippi and St. Croix rivers) and Chicago (Illinois and Fox rivers) outlets. Lakes Huron and Erie contained admixed mitochondrial lineages in part due to numerous access points, including the Fort Wayne (Wabash and Maumee rivers), Lower Peninsula of Michigan (Grand River valley), and Kirkfield (Kawartha Lakes) outlets. In contrast, populations in Lake Ontario, Georgian Bay of Lake Huron, and the St. Lawrence River were monomorphic, indicating a single but unidentified source. These patterns were consistent with many examples from the North American freshwater ichthyofauna.

Résumé : Nous avons identifié les refuges et les routes de migration des achigans à petite bouche (Micropterus dolomieu) vers les Grands Lacs à l'aide de 427 séquences mitochondriales provenant de l'ensemble de leur aire de répartition indigène. Globalement, les achigans à petite bouche sont arrivés dans les Grands Lacs après une dispersion de longue distance à partir de plusieurs refuges; la distribution de la variation génétique reflète les conséquences d'événements de vicariance, de dispersion et de paléogéologie. La proximité des lacs à des émissaires glaciaires est une variable prédictive plus puissante de la distribution résultante de la diversité mitochondriale que la migration entre les bassins versants. Les populations des terres hautes de l'est et de l'intérieur contiennent les haplotypes les plus divergents et les plus anciens, ce qui souligne leur rôle de refuges glaciaires et explique leur incidence élevée subséquente d'endémicité. Les lacs Supérieur et Michigan ainsi que le nord du lac Huron ont été colonisés par des achigans provenant d'un seul même clade mitochondrial qui a eu un accès aux émissaires Brulé-Portage (rivières Mississippi et Ste-Croix) et Chicago (rivières Illinois et Fox). Les lacs Huron et Érié contiennent des mélanges de lignées mitochondriales à cause en partie de leurs nombreux points d'accès, en particulier les émissaires de Fort Wayne (rivières Wabash et Maumee), de la péninsule inférieure du Michigan (vallée de la rivière Grand) et de Kirkfield (lacs Kawartha). En revanche, les populations du lac Ontario, de la baie Géorgienne du lac Huron et du fleuve St-Laurent sont monomorphes, ce qui indique une source unique, mais non identifiée. Ces patrons concordent avec de nombreux exemples observés dans l'ichtyofaune d'eau douce d'Amérique du Nord.
\end{abstract}

\section{Introduction}

Geological and topographic events have had a profound impact on the distribution of aquatic fauna in eastern and central North America. Interior rivers have undergone modifications as the result of marine intrusions, mountain uplift, and expansion and contraction of massive ice sheets. In response to episodic fluctuations, freshwater fishes acclimat- ized, migrated to suitable habitat, or restricted their distributions to isolated refugia. Although the Pleistocene may be too recent to have contributed substantially to divergent polymorphisms among populations leading to speciation (Klicka and Zink 1997, 1998), it has had a profound impact on determining the distribution of genetic variation in North American freshwater fishes. Understanding phylogeographic variation requires differentiating between the 
contributions of geological and climatic events and those from contemporary population-level processes.

The Great Lakes basin provides a superb system in which to investigate the complementary mechanisms of vicariance and dispersal that have shaped current phylogeographic patterns and population differentiation. During the Pleistocene, a series of glacial advances buried river courses, confined fish populations in geographically restricted refugia, and excavated lake basins. As the ice sheets retreated, meltwater formed periglacial lakes from which temporary outlets flowed and contacted southern refugia. With the loss of the ice sheet, isostatic rebound altered the topography and subsequently the drainage patterns of many river systems. Amidst these topographical changes, aquatic organisms dispersed northward via these temporary connections and watershed alterations until glacial advances forced range contractions. This ebb and flow of distribution and population sizes, in conjunction with the unstable nature of lakeoutlet connections, greatly affected phylogeographic patterns (e.g., Murdoch and Hebert 1997; Wilson and Hebert 1998) and faunal compositions (e.g., Bailey and Smith 1981; Mandrak and Crossman 1992) of Great Lakes' fishes.

Prior to the Pleistocene, the primary river basin in the central USA was the Teays-Mahomet system. Its traditional drainage course, as reconstructed by Wayne (1952) and Goldthwait (1991), ran northwestward from headwaters in the Eastern Highlands (North Carolina, Virginia, and West Virginia), across central Ohio, Indiana, and Illinois, before turning south into the Mississippi embayment. However, this conventional interpretation as a preglacial river may be overly simplistic (Gray 1991; Melhorn and Kempton 1991). Although the upper Ohio River (i.e., Allegheny basin) was isolated from the Teays system and flowed north into the Great Lakes basin (Underhill 1986), the relationship of the Teays-Mahomet system to the Wabash valley is unresolved. Various reconstructions include an autonomous Wabash basin (Teller 1973), a Teays-Wabash connection (Fidlar 1948) to the exclusion of the Mahomet valley, or a combination of the two (Wayne 1952) caused by an ice dam about 800000 years ago (Gray 1991). Numerous alternations in drainage patterns across this region are implicated as causal factors driving diversity (e.g., Hocutt et al. 1978; Ray et al. 2006) and explaining phylogeographic patterns of both terrestrial (e.g., Kozak et al. 2006; Placyk et al. 2007) and aquatic (e.g., Strange and Burr 1997; Bernatchez and Wilson 1998; Berendzen et al. 2003) organisms.

Here we evaluate the relative effects of glacial watershed connections and population histories on the distribution of mitochondrial variation in smallmouth bass (Micropterus dolomieu). Smallmouth bass are native to cool water streams with riffles and hard substrate and margins of clear water lakes of east-central North America (Scott and Crossman 1973; Trautman 1981; Page and Burr 1991). They colonized the Great Lakes from the Mississippian refugium (Bailey and Smith 1981; Mandrak and Crossman 1992) but likely used a number of routes to access them (Mandrak and Crossman 1992). Smallmouth bass are an ideal model organism with which to track dispersal and divergence associated with both ancient changes in streambeds and more recent glacial events that altered the Central Highlands and formed the Great Lakes. They will also provide a useful contrast with smaller and therefore presumably less vagile fish species (Ware 1978).

Within Lake Erie, smallmouth bass populations have diverged very little whether assessed by microsatellites or mitochondrial DNA variation (Borden and Stepien 2006; Stepien et al. 2007). Instead, higher levels of differentiation appear between riverine and lacustrine populations and among riverine populations of both smallmouth bass (Stepien et al. 2007; Borden 2008a) and its sister species, the northern spotted bass (Micropterus punctulatus punctulatus) (Coughlin et al. 2003). Microsatellite markers suggest some divergences between populations of the Great Lakes and the Mississippi-Ohio rivers and even fewer among Great Lakes populations (Stepien et al. 2007). Therefore, to reconstruct dispersal patterns, we applied mitochondrial genes, as they can provide both ancestral and derived markers. Thus, our primary objectives are to explain the distribution of mitochondrial variation among populations of smallmouth bass by (i) determining the geographical and evolutionary origins of populations in the Great Lakes, (ii) identifying the dispersal routes used to access each lake, and (iii) assessing the relative impacts of vicariance and dispersal on their phylogeography.

\section{Materials and methods}

\section{Sample collection}

Smallmouth bass were collected throughout their native range (Fig. 1; Appendix A, Table A1) using seines, gill nets, electrofishing, or angling. Populations from Lake Erie (Borden and Stepien 2006) and four of its tributaries (Borden 2008a) comprised $\sim 30 \%$ of the data used herein. Fin clips were taken in the field and, in most instances, were stored immediately in 95\% ethyl alcohol. Two congeneric species were used as comparative material (northern largemouth bass, Micropterus salmoides salmoides; northern spotted bass). The first author maintains a set of either fin clips or extracted genomic DNA for most specimens, and replicate fin clips were donated to the tissue collection at the Ohio State University Museum of Biological Diversity (Columbus, Ohio).

\section{Sequencing methods}

DNA extraction, gene amplification, amplicon cleanup, and automatic sequencing protocols largely follow those described in Borden and Stepien (2006). Additional primers (Cytb-F, 5'-ATGGCAAGCCTCCGAAAAAC-3'; Ctrl-R, 5'CGAGGAATAATATCAAGTAATG-3') were developed and applied successfully to yield an amplicon of approximately $1700 \mathrm{bp}$ that was composed of the entire cytochrome $b$ gene (1140 bp), the $5^{\prime}$ end of the control region (425 bp), and the intervening tRNA-Thr and tRNA-Pro genes (121 bp total). Because the mitochondrial genome is inherited as a single locus, cytochrome $b$ and control region sequences were concatenated for analysis. Haplotype identification labels were consistent with those reported in Borden and Stepien (2006) and Borden (2008a, 2008b). Sequences were read and aligned by eye and then submitted to GenBank.

\section{Phylogenetic construction of a gene tree}

Relationships among haplotypes were estimated using 
Fig. 1. Collection sites $(n=71)$ of smallmouth bass across the Great Lakes basin and central USA (inset shows location within CanadaUSA). Shading of sites is consistent with Figs. 3 and 5 and indicates the predominant mitochondrial lineage present. The figure is not intended to show the distribution of every haplotype lineage or the haplotype composition at each collection site. Site numbers are consistent with Appendix A (Table A1). Sites 21-30 (Lake Erie) and 35, 37, and 38 (Chagrin, Cuyahoga, and Grand Rivers, respectively) are a composite of sampling stations as detailed in Borden and Stepien (2006) and Borden (2008a), respectively. The maximum extent of the Wisconsinan ice sheet is represented by a dotted line after Péwé (1983). The unlabelled Great Lake is Lake Erie. The shaded boundaries of the Interior (Ouachita and Ozark) and Eastern Highlands approximate Mayden (1987), and only a portion of the Ouachita Highlands has been included.

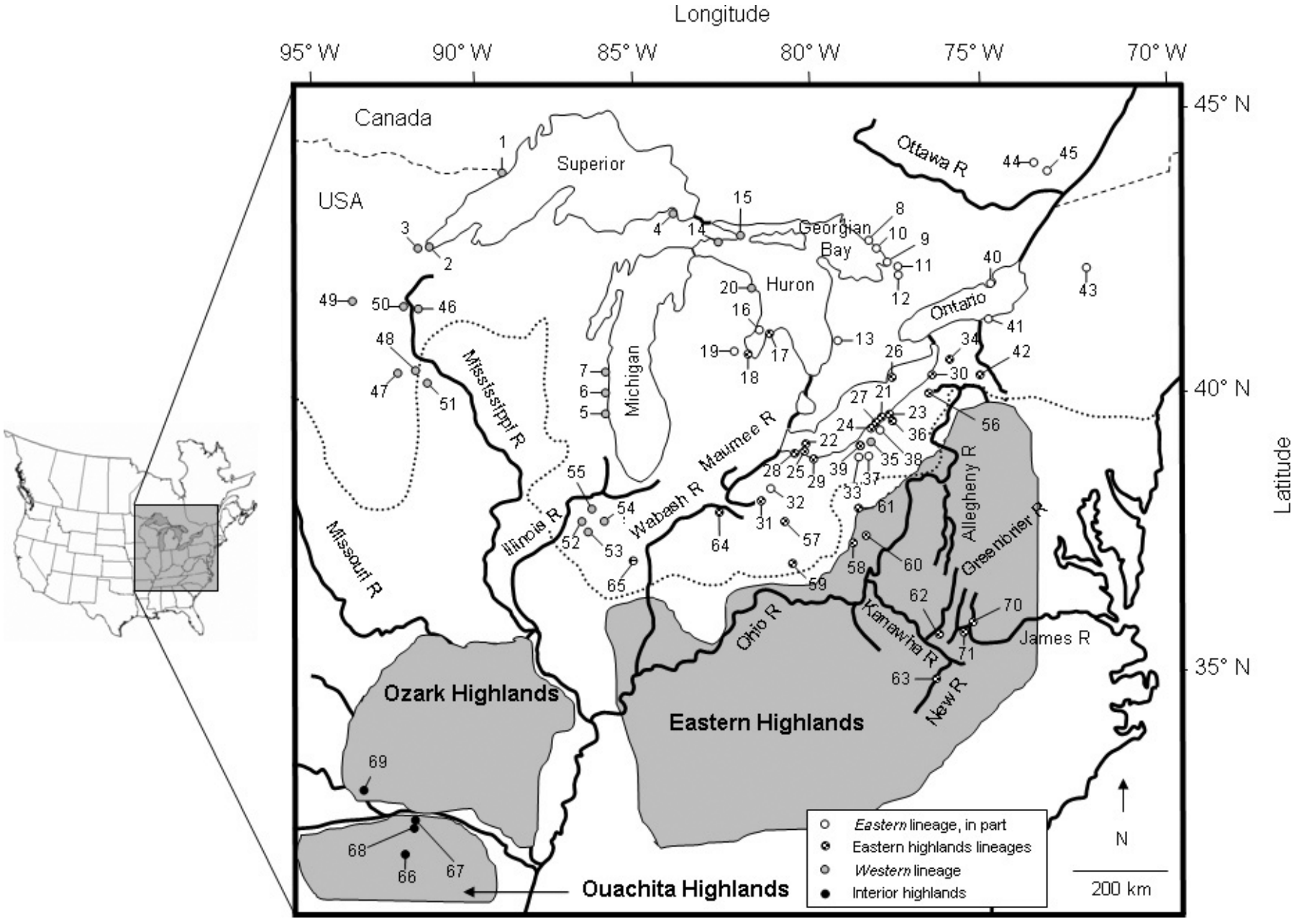

maximum likelihood (ML) and Bayesian (BY) criteria to identify evolutionary lineages. Nucleotides were partitioned by gene to identify the substitution model of best fit using the Akaike information criterion (Posada and Buckley 2004) as implemented in MrModeltest version 2.3 (Nylander 2004). Four iterations of MrModeltest were applied to each gene to assure consistency. An insufficient number of substitutions in the first and second codon positions precluded accurate parameter estimation, thus cytochrome $b$ was not partitioned by codon position. ML analyses were conducted in TREEFINDER (Jobb 2008) with 10000 replicates and 1000 pseudoreplicates of nonparametric bootstrapping (Felsenstein 1985) to estimate nodal support. Two Bayesian analyses using MRBAYES version 3.1.2 (Huelsenbeck and Ronquist 2001; Ronquist and Huelsenbeck 2003) were performed to confirm convergence, each of which consisted of two runs, four chains, Markov chain Monte Carlo algorithm to estimate posterior probabilities, and sampling of every thousandth tree for $6.0 \times 10^{6}$ generations. Analyses were evaluated for convergence of the runs using the parameters and guidelines in Huelsenbeck and Ronquist (2001). The first $25 \%$ of trees were discarded (burn-in $=1500$ ) as the log-likelihoods had stabilized by that point. The remaining trees (4501 per run) were collapsed into a 50\% majority rule consensus tree with posterior probabilities as indicators of nodal support. A likelihood ratio test (LRT; Huelsenbeck and Crandall 1997) was used to test for a constant rate of evolution among lineages using PAUP* version 4b10 (Swofford 1998). Trees were constructed assuming both unconstrained and constrained (molecular clock) evolutionary rates, and their likelihoods were compared using a likelihood ratio test. The LRT statistic $(-2 \log \Lambda)$ was compared with a $\chi^{2}$ distribution at an alpha of $0.05(\mathrm{df}=s-2$, where $s$ is the number of sequences; Felsenstein 1981) in which failure to reject the null hypothesis of evolution under a molecular clock was indicated by a $P$ value $>0.05$. 


\section{Construction and analysis of a haplotype network}

Nested clade phylogeographical analysis (NCPA; Templeton et al. 1995; Templeton 2004) was used as an additional tool to assess phylogeographic history by identifying historical and contemporary processes that have affected the geographical distribution of genetic variation. This approach is complementary to phylogenetic analysis of haplotypes, which violates assumptions of bifurcating lineages, namely that ancestral haplotypes can be retained in a population (Posada and Crandall 2001). To apply NCPA, a haplotype network was constructed using TCS version 1.18 (Clement et al. 2000) in automated nested clade analysis (Panchal 2006; Panchal and Beaumont 2007), which follows the procedures outlined by Templeton et al. (1987), Crandall (1996), and Templeton (2002). Internal loops and cycles within the network were resolved using results from gene tree construction and coalescence theory. Haplotypes in the network were then progressively grouped as inclusive clades beginning with tip haplotypes and proceeding toward internal haplotypes until the entire network comprised one clade. The relationship between nesting structure and the geographical distribution of haplotypes was described using two summary statistics (Dc and Dn), with tip clades assumed to be younger than internal clades (Castelloe and Templeton 1994). Clades were then randomly permutated ( $n=10000)$ across sampling sites to create $P$ values (GeoDis version 2.2, Posada et al. 2000). Finally, an automated inference key was used to interpret these two summary statistics. When the null hypothesis of no association between haplotype clades and their geographical distributions was rejected, a key identified mechanisms consistent with observed patterns of nested haplotypes (Templeton 2004).

NCPA has received critical reviews due, in part, to claims of the high frequency of false positives, deficiencies in the inferences drawn, and lack of error assessment in the inference chain (Knowles and Maddison 2002; Panchal and Beaumont 2007; Petit 2008). These criticisms drew rebuttals from Templeton $(2004,2008)$ and Garrick et al. (2008). In this study, NCPA is not used to the exclusion of other methods, but rather as one of several tools to explore phylogeographic patterns.

\section{Assessment of population diversity, demographic history, and structure}

Diversity indices ( $n$, the number of specimens sequenced; $n_{\mathrm{H}}$, the number of unique haplotypes; $h$, haplotype diversity; $\pi$, nucleotide diversity) were calculated using Arlequin version 3.1 (Excoffier et al. 2006). The relationship between $h$ and $\pi$ was then used to infer demographic histories sensu Grant and Bowen (1998). Populations and lineages that have expanded or contracted rapidly, either demographically or geographically, often leave genetic signals. Changes in population demographics were identified using Fu's test of selective neutrality ( $\mathrm{Fu} 1997)$, mismatch analysis based on the frequency distribution of pairwise differences between haplotypes (Rogers and Harpending 1992; Schneider and Excoffier 1999), and the population parameter tau ( $\tau$, time to expansion). Using these indices, a large negative value of $F_{\mathrm{S}}$, a unimodal distribution of haplotype differences, and a small tau all indicated recent population expansion, demo- graphically or spatially. Tau was also converted to an absolute date using the relationship $t=\tau / 2 u$, where $t$ is time in generations and $u$ is the product of mutation rate per site per year $\times$ number of years per generation $\times$ number of base pairs. Mutation rate was calculated by dividing the time since divergence of smallmouth and spotted bass (1.67 \pm 0.45 million years, bootstrap confidence interval; Near et al. 2005) by a genetic distance (corrected mean pairwise differences, $\left.\delta_{\mathrm{A}}=\delta x y-1 / 2[\delta x+\delta y]=4.46\right)$ and multiplying by the number of base pairs ( $840 \mathrm{bp}$ in this case). We assumed that females matured at approximately 5 years (Scott and Crossman 1973). Tau and associated divergence dates were rough estimates, and thus attempts to correlate these dates with specific geological events were avoided, particularly in the context of very recent divergences (i.e., $<2$ million years).

\section{Results}

\section{Mitochondrial haplotype statistics}

The number of individuals per locality depended in part on collection method, effort, and successful sequencing (121 individuals per site, median $=5$; Appendix A, Table A1). Some collections were composites of multiple sampling sites in close proximity. In the end, 475 smallmouth bass were sequenced for cytochrome $b$ (appendix $\mathrm{C}$ in Borden $2008 b$ ), and 511 smallmouth bass were sequenced for the control region (appendix D in Borden 2008b), yielding 22 and 21 haplotypes, respectively. Within the cytochrome $b$ gene of smallmouth bass, polymorphic loci occurred in either the first ( 2 of 24 substitutions) or third (22 of 24) codon positions, and only one nonsynonymous substitution was identified (transversion at bp 982, leucine-valine).

From these individuals, 427 smallmouth bass were sequenced successfully for both mtDNA regions, yielding 45 composite haplotypes (Appendix B, Table B1) derived from 36 polymorphic sites ( 24 sites in cytochome $b, 12$ sites in the control region) displaying 39 substitutions (27 transitions, 12 transversions). Composite haplotypes were represented by a few high-frequency haplotypes with numerous closely related but much more rare sequences (38 of 45 haplotypes had a frequency $<2 \%$, including 15 singletons). A comprehensive list of all smallmouth bass sequenced and their component mtDNA haplotypes can be found in appendix F of Borden (2008b). Four spotted bass (Big Darby Creek, Ohio, $n=1$; Little Vermilion River, Illinois, $n=1$; and Duck River, Tennessee, $n=2$ ) yielded two unique composite haplotypes; a single largemouth bass (Blanchard River, Ohio) was sequenced.

\section{Phylogenetic relationships of mtDNA haplotypes}

The HKY+I substitution model (Hasegawa et al. 1985) best described cytochrome $b(\mathrm{ts} / \mathrm{tv}=2.05, I=0.72)$, and the $\mathrm{GTR}+\mathrm{I}+\Gamma$ substitution model (Lanave et al. 1984; $\mathrm{rAC}=$ $0.00, \mathrm{rAG}=2684629.25, \mathrm{rAT}=2907489.50, \mathrm{rCG}=0.00$, $\mathrm{rCT}=14348070.00, \mathrm{rGT}=1.00, I=0.91, \Gamma=1.11)$ was chosen from two models identified (the other being GTR+I) for the control region. Substitution rates rAC and rCG were converted to 0.0001 in PAUP* analyses, in which both partitions failed to reject the molecular clock $\left(\chi_{\text {cytb }}^{2}=55.07\right.$, $\chi_{\text {control }}^{2}=47.26, P>0.05$ for $\left.\chi_{\mathrm{df}=45, \alpha=0.05}^{2}=61.66\right)$. The 
Fig. 2. Consensus phylogram from mixed-model Bayesian analysis of 45 smallmouth bass mtDNA haplotypes. Numbers along branch lengths are bootstrap values (maximum likelihood, ML) followed by posterior probabilities (Bayesian, BY). When only a single value is present (posterior probability), the bootstrap value is less than 50\%. Italicized labels circumscribe haplotypes by watershed of which the Ouachita and Arkansas (i.e., M. dolomieu velox) delineations follow Stark and Echelle (1998).

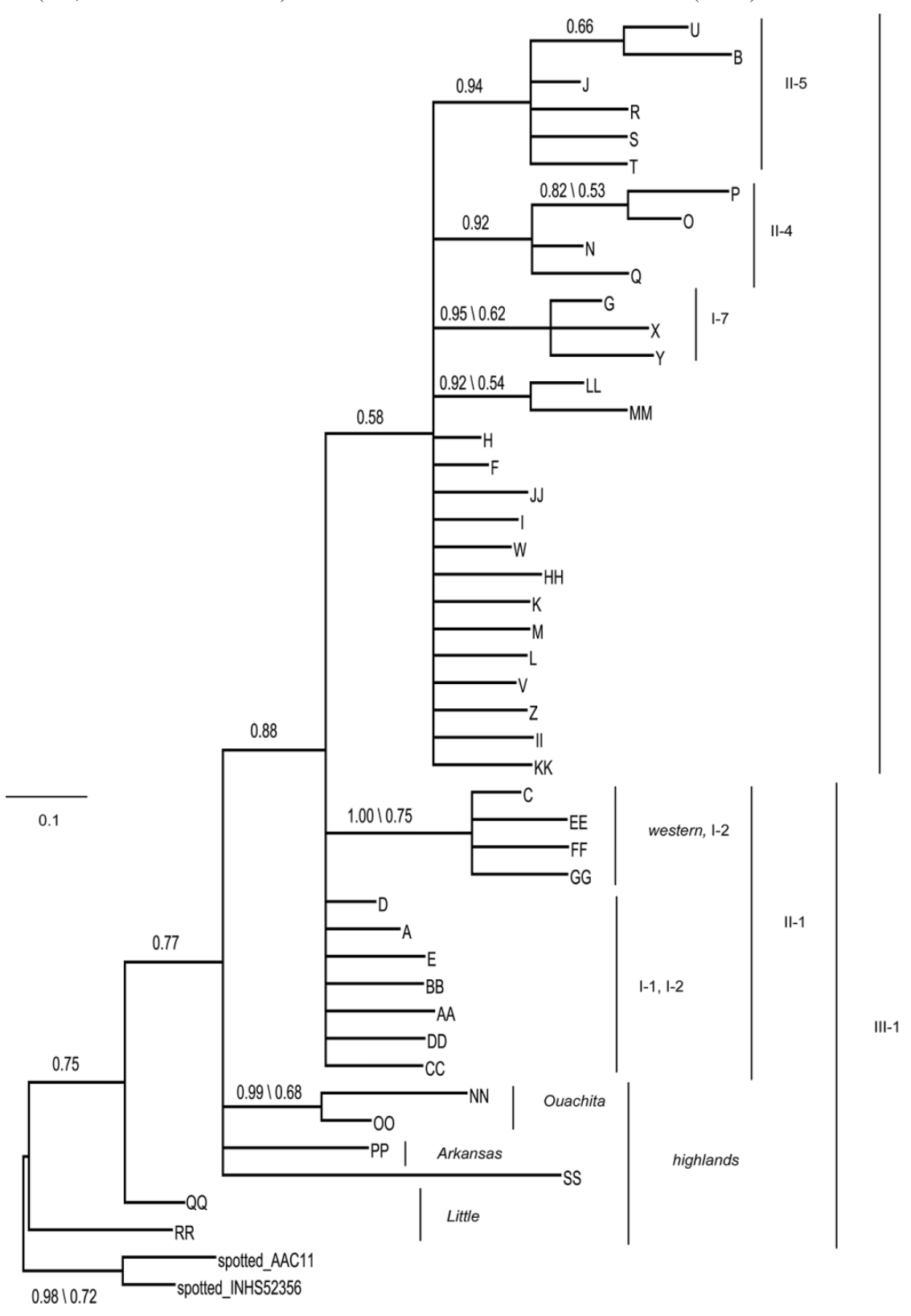

large number of rare haplotypes with small divergences resulted in large polytomies and low support for some nodes in ML $(-\ln L=1532.96$, not shown) and BY consensus trees (Fig. 2). Consequently, discussion emphasized lineages with greater support or general trends across the BY consensus tree. Both runs within each BY analysis converged, as did BY analyses on the same topology (average harmonic means of analysis $1=-1618.86$ and analysis $2=-1615.53$ ). Groups of phylogenetically related haplotypes were referred to as lineages and italicized, whereas haplotype clades identified in NCPA were labeled with Roman numerals (identifying the step clade) and Arabic numbers.

Smallmouth bass from the Interior Highlands and one haplotype from the Eastern Highlands (haplotype SS) were located basally and are hereafter referred to as "highlands" out of convenience rather than an indication of monophyly. Structure among Interior Highland watersheds was evident. Three bass (haplotype SS) collected in headwaters of the New and James rivers (Virginia, West Virginia) were divergent from all other smallmouth bass by 7.34 pairwise differences. To put this in perspective, spotted and smallmouth bass mtDNA haplotypes had a net sequence divergence of only 4.46 pairwise differences.

The remaining haplotypes formed a single lineage within which differentiated groups possessed both phylogenetic and geographical affinities. For one, a well-supported "western" lineage contained haplotypes distributed primarily in the upper Great Lakes (Superior, Michigan, Huron excluding 
Fig. 3. Nesting structure of one potential network of 45 haplotypes from 427 smallmouth bass recovered from an automated NCPA. The entire network comprises a four-step clade. Solid lines circumscribe three-step clades; thick broken lines circumscribe two-step clades; thin broken lines circumscribe one-step clades. Only those clades referred to in the text are labeled, and these labels are consistent with Fig. 2. Haplotype $\mathrm{C}$ (enclosed in a star) has the highest frequency $(n=103)$, whereas haplotype H (enclosed in a box) has the largest root probability (Castelloe and Templeton 1994).

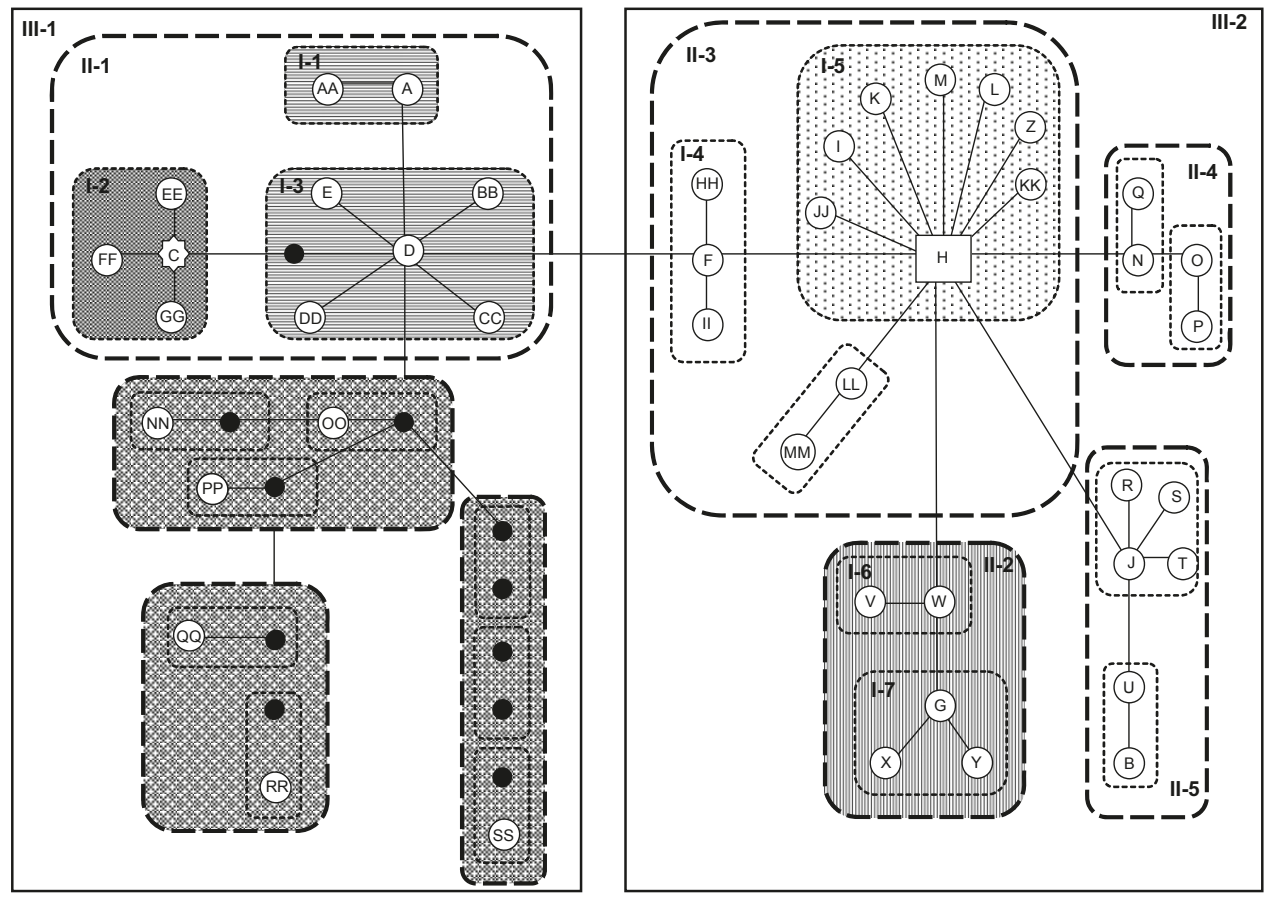

Georgian Bay) and tributaries of the Mississippi and Illinois rivers. An "eastern" lineage was comprised of derived haplotypes that were distributed across Lakes Huron, Erie, Ontario, and their tributaries, the St. Lawrence River, and major tributaries of the Ohio River (Allegheny, Greenbrier, Wabash rivers). The majority of these sites were ice-covered during the Wisconsinan with the exception of the Greenbrier (site 62) and possibly the lower Wabash (site 65) rivers. Within the eastern clade, smaller lineages were centered on Lake Erie and extended into adjacent basins to the east (Allegheny), southwest (Wabash), and south (northern Ohio River tributaries), or some combination thereof. Again, congruence between phylogeny and geography was present, although not to the same extent as in western and highlands lineages. Divergences within the eastern lineages were smaller $(<1.5$ mean pairwise differences) than those found in the western lineage and the seven haplotypes $(\mathrm{A}, \mathrm{D}, \mathrm{E}$, $\mathrm{AA}, \mathrm{BB}, \mathrm{CC}, \mathrm{DD})$ with which the western lineage forms a polytomy ( $\geq 3$ mean pairwise differences). An eclectic assortment of eastern bass (16 of 215 bass) was recovered at geographically distant sites in the Mississippi River $(n=2)$, Lake Superior $(n=6)$, Lake Michigan $(n=7)$, and northernmost Lake Huron $(n=1)$. They were minor components of populations characterized by more basal and divergent western haplotypes.

\section{Dispersal patterns and population demographics}

Overall, NCPA supported multiple events of dispersal followed by population expansion and (or) isolation by distance. Histories of population demographics inferred from haplotype and nucleotide diversities, relative expansion times, and a loss of nucleotide and haplotype diversities within progressively nested lineages and clades (Figs. 2, 3) across a latitudinal gradient (Fig. 4) supported further our primary conclusion: smallmouth bass evolution was marked by vicariance events among primarily basal lineages and multiple colonization events of more derived lineages with some in situ divergence.

NCPA yielded a single four-step clade that was itself comprised of two three-step clades (Fig. 3). Clade III-1 was comprised of highlands and western lineages with distributions consistent with contiguous range expansion (III-1, I-1) and isolation by distance (I-2, I-3). The oldest and most stable populations occurred in the Interior and Eastern Highlands based on the co-occurrence of high haplotype diversity $(h>$ $0.5)$ and the largest nucleotide diversity $(\pi>0.4 \%)$, in addition to the absence of evidence for recent population expansion $\left(F_{\mathrm{S}}=1.4, P\right.$ value $=0.77 ;$ mismatch distribution $P$ value $=0.09 ; \tau=6.9, \sim 1.3$ million years ago (mya)). Sampling sites that contained western haplotypes were characterized by both low haplotype and nucleotide diversities consistent with a founding group characterized by a single mitochondrial lineage or a small founding population experiencing substantial genetic drift $\left(F_{\mathrm{S}}=-2.9, P\right.$ value $=0.02$, mismatch distribution $P$ value $=0.37, \tau=3.0, \sim 0.5$ mya).

The large eastern lineage (III-2) was comprised of derived haplotypes with low levels of divergence. As predicted, signatures of recent population expansion were strong $\left(F_{\mathrm{S}}=\right.$ $-20.6, P$ value $=<0.01$; mismatch distribution $P$ value $=$ $0.03 ; \tau=1.8, \sim 0.3$ mya) for a group of derived haplotypes that were distributed across multiple, previously glaciated basins. Several nested clades within III-2 were more ro- 
Fig. 4. Haplotype (solid circles, continuous line) and nucleotide (open circles, broken line) diversities of smallmouth bass grouped into 17 water bodies versus latitude. Sixteen smallmouth bass with distributions consistent with human translocations were removed. Haplotype regression line: $y=-0.07 x+3.57, r^{2}=0.56, p<0.01$. Nucleotide regression line: $y=-0.03 x+1.54, r^{2}=0.62, p<0.01$.

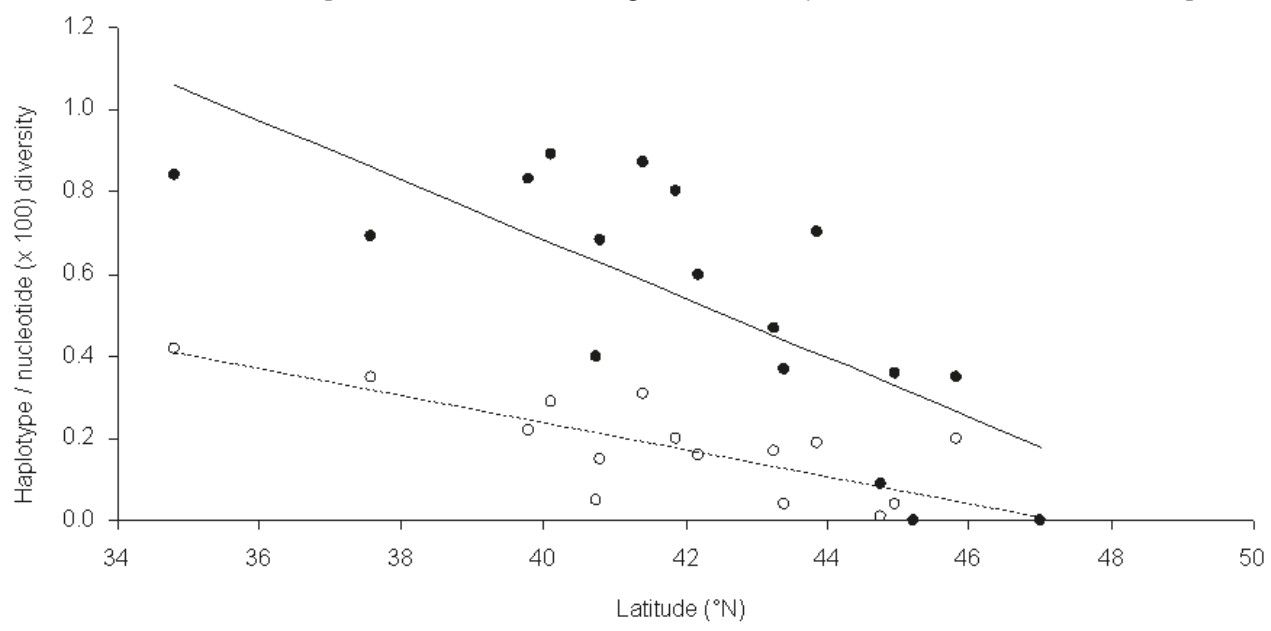

bustly supported and distributed nonrandomly due to isolation by distance (II-3, I-6), contiguous range expansion (II-2), or both (I-4, I-7). Ambiguous mechanisms of divergence (e.g., long-range dispersal or local extirpation in clades III-1 and I-5) were due to unsampled populations in the Kentucky, Tennessee, Cumberland, and White rivers. Given that these rivers were part of the native and current distribution of smallmouth bass (Robison and Buchanan 1988; Etnier and Starnes 1993) and unglaciated during the Pleistocene, local extirpation was not a realistic inference.

\section{Discussion}

\section{Distribution of genetic variation in the Eastern and Interior Highlands}

The highlands played a significant role as glacial refugia during the Pleistocene, as shown by high degrees of genetic endemism within this region, evidence of stable populations, basally located haplotypes, and large nucleotide and haplotype diversities that predate the Wisconsinan (assuming mtDNA mutation rate of $1.17 \%$ per million years; Near et al. 2003). It is not surprising then that numerous endemic fishes characterize both the Eastern (Hocutt et al. 1978; Starnes and Etnier 1986) and Interior (Mayden 1985, 1987; Wiley and Mayden 1985) Highlands. In fact, the Interior Highlands (Ouachita and Ozark Mountains) appear to contain the greatest genetic diversity of smallmouth bass (Stark and Echelle 1998). One population that is endemic to tributaries of the middle Arkansas River along the western and southern slopes of the Ozark Mountains (Koppelman and Garrett 2002) was even raised to subspecific status, M. dolomieu velox, by Hubbs and Bailey (1940).

Likewise, bass from the Eastern Highlands possessed high levels of mitochondrial diversity, including endemic haplotypes and one anomalous sequence so divergent as to likely predate the split between smallmouth and spotted bass. As remnants of the Teays River (Hocutt et al. 1978), populations in the Greenbrier, New, and Kanawha rivers may contain ancient lineages. The presence of this haplotype in the upper Kanawha basin (i.e., Greenbrier River) could reflect a relic population or incomplete lineage sorting, in which case, evolution of this divergent haplotype in situ refutes the expectation that smallmouth bass are introduced in the upper Kanawha (Hocutt et al. 1986). Distinctive populations in the Kanawha basin are replicated in other fishes, for example, crystal darters (Crystallaria asprella) at a magnitude often concordant with interspecific divergence (Morrison et al. 2006) and a divergent group of rainbow darters (Etheostoma caeruleum) that colonized the Ohio River (Ray et al. 2006).

In smallmouth bass, the high diversity in populations on the western slopes of the Appalachian Mountains contrasts with a depauperate James River gene pool on the eastern slopes. The most parsimonious explanation is headwater diversion of the New River eastward (Hocutt et al. 1978), in effect, passive dispersal into non-native habitat (Underhill 1986) followed by drift that could quickly homogenize populations. Similar relationships among cross-divide populations are found in northern hogsuckers (Hypentelium nigricans; Berendzen et al. 2003), mottled sculpins (Cottus bairdi; Howard and Morgan 1993), and rosyface shiners (Notropis rubellus; Berendzen et al. 2008).

\section{Distribution of genetic variation across the Great Lakes}

The distribution of mitochondrial lineages across the Great Lakes reflects the youth of the Lakes and is a product of the geographical proximity of proglacial lake basins and temporary outlets. Connectivity among basins appears to be relatively less important in explaining shared alleles among lakes; instead, sequential dispersal events from multiple refugia best explain genetic patterns among basins. For example, fish in the upper Great Lakes and upper Mississippi River are characterized by the "western" lineage, an older but not diverse group of haplotypes that is tightly bound geographically, suggesting a vicariance model of evolution. This phylogeographic pattern among the upper Great Lakes is replicated in the brown bullhead (Ameiurus nebulosus; Murdoch and Hebert 1997) and the brook stickleback ( $\mathrm{Cu}$ laea inconstans; Gach 1996), the latter of which contains approximately one-half of the heterozygosity relative to populations in southern Lake Huron, Ohio, and Pennsylvania.

To reach the upper Great Lakes, smallmouth bass likely 
accessed glacial Lake Duluth (ancestral Lake Superior) through the Brule-Portage outlet (Mississippi and St. Croix rivers) and glacial Lake Chicago (ancestral Lake Michigan) through the Chicago outlet (Fox and Illinois rivers). Zoogeographic patterns suggest that bass also used the Warren outlet (Minnesota River; Mandrak and Crossman 1992) but did not penetrate the Red River basin to any great extent. The Chicago outlet may be as old as 14000 years BP and may have lasted 8000 years (Bailey and Smith 1981; Mandrak and Crossman 1992), thus allowing smallmouth bass early and multiple opportunities to access the Lake Michigan basin despite Lake Michigan bass populations being characterized by western haplotypes. Farther west, the Missouri refugium and glacial Lake Agassiz were apparently not important refugia of smallmouth bass (Burr and Page 1986; Underhill 1986; Mandrak and Crossman 1992).

In contrast to the upper Great Lakes, bass populations in the central Great Lakes (Huron and Erie) show high haplotype but low nucleotide diversities. A large number of colonization routes served them, which suggests that populations in these lakes are admixed lineages rather than stable populations of older haplotypes that excluded secondary dispersers (Cox and Hebert 2001). In fact, admixture resulting from secondary contact of divergent lineages is responsible for a hot spot of taxonomic and genetic diversity lying between Lakes Huron and Erie (Swenson and Howard 2005). Populations in northern Lake Huron were likely established from source populations in Minnesota and Wisconsin that dispersed along either the Upper Peninsula of Michigan or the shoreline of ancestral Lake Superior. Eastward dispersal is consistent with the observation that bass in northern Lake Huron are genetically more similar to "western" haplotypes than are bass from the remainder of Lake Huron. Eastward dispersal from Minnesota and Wisconsin into northern Michigan is consistent with phylogeographic patterns in the eastern garter snake (Thamnophis sirtalis; Placyk et al. 2006) and the brook stickleback (Gach 1996). In contrast, populations in Georgian Bay of Lake Huron are derived from eastern populations in Lake Ontario that dispersed westward using the Kirkfield outlet (see below), and populations in southern Lake Huron have greater affinity with those in Lake Erie.

Shared alleles among lake and riverine populations (some of which occur above impassable barriers) suggest that bass may have accessed the Erie basin either over the relatively low Portage Escarpment that separates the Great Lakes and Ohio River basins in northern Ohio or through the upper Ohio (Allegheny) and Monogahela rivers when the preglacial Pittsburgh River flowed north (Hocutt et al. 1986). The Monogahela River, in turn, was positioned to receive refugial populations dispersing from the Greenbrier River (Hocutt et al. 1978). However, arguably the most influential route into Lake Erie, and subsequently southern Lake Huron, was the Fort Wayne outlet that connected several glacial versions of Lake Erie (Maumee, Arkona, Whittlesey) to the Wabash valley (Teller 2004). It is an important dispersal corridor not only for many taxonomically diverse fishes (Mandrak and Crossman 1992), but also for freshwater mussels (Unionidae; Graf 2002). It may have been the first outlet to form following the retreat of the ice sheet (14 $100{ }^{14} \mathrm{C}$ years BP; Teller 2004) and could have remained open for 2000 years (Underhill 1986). Lake Maumee extended northward as ice melted and pooling water reached glacial Lake Saginaw (southern Huron basin) to form Lake Arkona (13400 ${ }^{14} \mathrm{C}$ years BP; Teller 2004). The appearance of this continuous shoreline would have facilitated dispersal of smallmouth bass (Rubec 1975) into the southern Huron basin and is supported by shared alleles in smallmouth bass across the upper Wabash basin, western basin of Lake Erie, and southern Lake Huron including Saginaw Bay. This pattern is also observed in rainbow darters (Ray et al. 2006), brook sticklebacks (Gach 1996), and cypriniforms (Gerking 1947), the latter of which Gerking used to propose numerous Mississippi - Great Lakes connections in northern Indiana.

Populations of smallmouth bass within the Wabash basin are more genetically similar to populations in southern Ohio and the Eastern Highlands relative to geographically proximate populations in the Illinois River. This phylogeographic pattern traces the course of the Teays River through unglaciated portions of the Ohio and Wabash basins to the exclusion of the Illinois River (Mahomet system) and is indicative of northern hogsuckers (Berendzen et al. 2003), rainbow darters (Ray et al. 2006), rosyface shiners (Berendzen et al. 2008), and introgression patterns between common and striped shiners (Dowling et al. 1997). Interestingly, mitochondrial evidence does not support substantial gene flow between upper and lower Wabash populations of smallmouth bass, which share only two haplotypes. Whereas both populations have high haplotype diversities ( $h=0.68$ and 0.89 for upper and lower, respectively), the lower Wabash population has a nucleotide diversity double that of the upper population and likely reflects a more dynamic hydrogeological history (Fidlar 1948; Wayne 1952; Teller 1973).

Finally, populations in Lake Ontario, Georgian Bay, and the St. Lawrence River basin share a common clade (I-5) similar to the pattern found in brown bullhead (Murdoch and Hebert 1997). This clade is comprised of recently derived haplotypes $(\leq 0.3$ mya) that are distributed across primarily previously glaciated regions (Fig. 5) and multiple basins, suggesting a dispersal mechanism of evolution. Moreover, their absence in northern and western Lake Huron suggests a southeast to northwest direction of dispersal before the closure of the Kirkfield outlet (11800 BP; Eschman and Karrow 1985). Clade I-5 could have originated in the Erie basin as $21 \%$ of bass in Lake Erie carry such haplotypes, with dispersal into Ontario prior to the formation of Niagara Falls (12500 years BP; Mandrak and Crossman 1992). Otherwise, the geographical origin of clade I-5 remains unresolved.

Overall, Great Lakes smallmouth bass reveal a history of multiple and sequential dispersal events from genetically divergent founding populations. Populations were subsequently isolated due to the closure of outlets or restricted gene flow across large distances of contiguous habitat. Such inferences are consistent with predictions of spatial expansion by populations following the removal of geographical constraints (Rousset 1997) such as glacial fronts. Moreover, relationships between phylogeny and geography emphasize the significant roles of paleodrainage patterns, vicariance, and dispersal on populations of smallmouth bass. Following establishment of colonists, ecological attributes such as small home ranges (Ridgway et al. 2002) and nest site fidel- 
Fig. 5. Proposed colonization routes of founding smallmouth bass populations and their geographical origins based on mitochondrial DNA lineages. Outlet names follow Mandrak and Crossman (1992). Question marks indicate unknown genetic affinity of unsampled smallmouth bass populations.

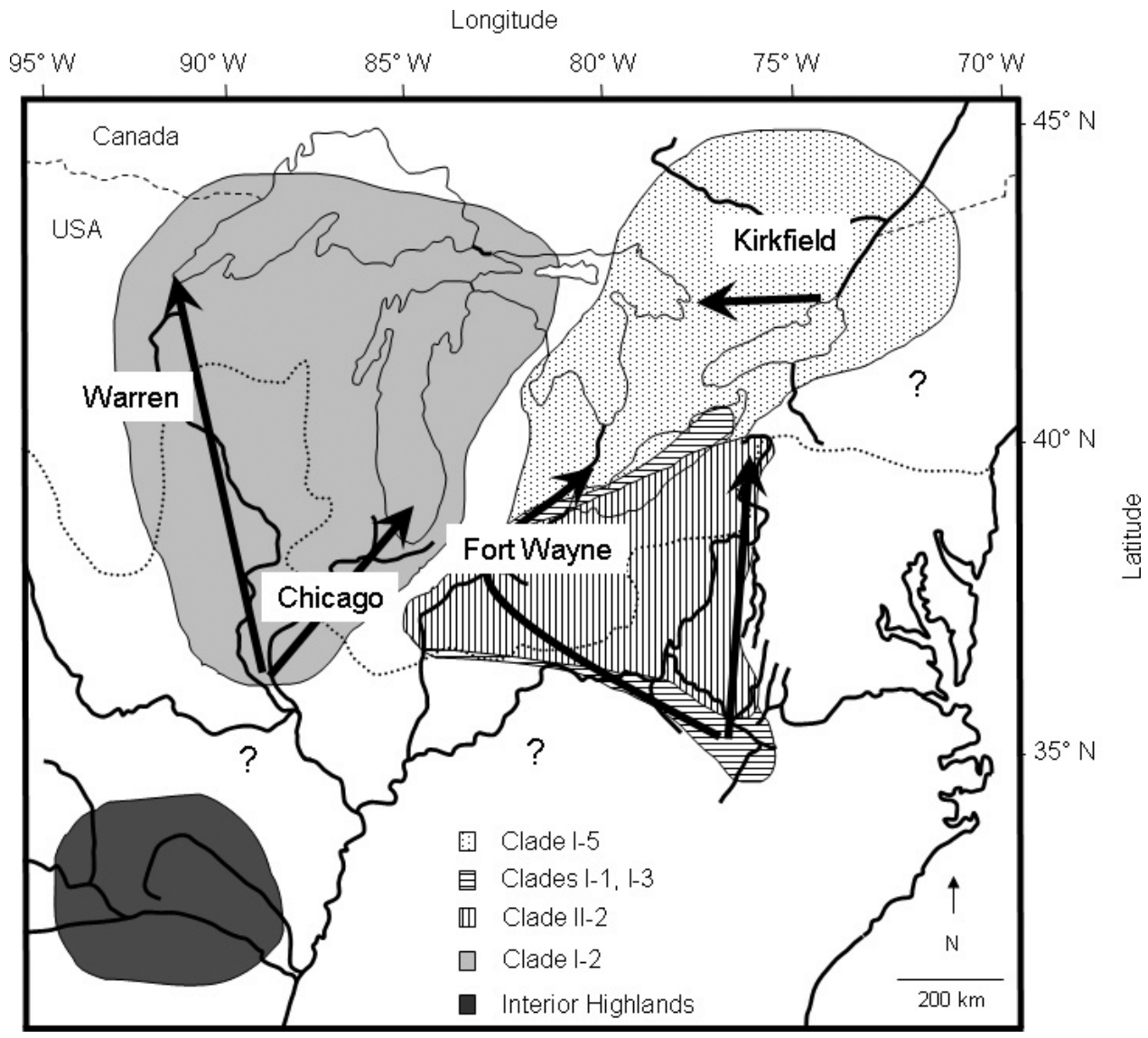

ity (Ridgway et al. 1991) may have contributed to the maintenance of genetic integrity in local populations. Though inferences using a single locus from one species must be dampened, phylogeographic patterns of smallmouth bass are shared with other Great Lakes' and North American freshwater fishes, indicating faunal-level responses to the region's geological history (Bernatchez and Wilson 1998).

\section{Contemporary problems of translocated fish}

Given the popularity of smallmouth bass as a sport fish, the pressure to stock them, both within and beyond their native distribution, is high. Smallmouth bass have been regionally (e.g., Rainy and Red River basins in northern Minnesota; Eddy et al. 1972) and broadly (e.g., Europe and Japan; Cowx and Maldin 1998) introduced. A priori, there are no analytical methods to ensure that introduced haplotypes are not included, and therefore, assessment of anomalous haplotypes may be the only reasonable option of detecting introduced alleles. Effectively identifying translocated fish is a function of the degree of divergence between native and introduced haplotypes (i.e., greater divergences are more easily detected) and the accuracy of circumscribing haplotype distributions (i.e., avoiding large gaps in the geographical sampling). Useful criteria to identify translocated alleles may include disjunct and peripheral distributions relative to other bass with the same allele, low frequencies and high divergences relative to native haplotypes in these pe- ripheral populations, and stocking histories. Failure to identify and remove introduced alleles may inflate estimates of genetic diversities, decrease population divergences, and alter inferences of population demographics and structure.

Using these criteria, 16 putatively translocated individuals possessing eastern haplotypes were identified in populations of the upper Great Lakes and Mississippi River basin. Introductions may have occurred from brood stock of unknown genetic origin in the Sheboygan and Milwaukee rivers of Lake Michigan (T.E. Burzynski, Wisconsin Department of Natural Resources, 600 E. Greenfield Avenue, Milwaukee, WI 53204, USA, personal communication, 2005) or ballast water transfer into the St. Louis estuary of Lake Superior in light of the fact that Duluth Harbor is the largest in-ballasting port on the Great Lakes (D.M. Pratt, Wisconsin Department of Natural Resources, 1401 Tower Avenue, Superior, WI 54880, USA, personal communication, 2007).

\section{Acknowledgements}

Many people contributed to this work, most notably through their generous contributions of samples: J. McClain, A. Bowen, and A. Kowalski (US Fish and Wildlife Service, Alpena, Michigan); L. Witzel, A. Cook, E. Arnold, and E. Wright (Ontario Ministry of Natural Resources (OMNR), Lake Erie Management Unit); J. Hoyle (OMNR, Lake Ontario Management Unit); M. Nadeau and D. Gonder (OMNR, Upper Great Lakes Management Unit); K. 
Schmidt, B. Stefanoky, N. Proulx, and J. Lehner (Minnesota Department of Natural Resources (DNR)); T. Burzynski (Wisconsin DNR); J. Johnson, S. DeWitt, J. Diemond, M. Werda, K. Glomski, and D. Fielder (Michigan DNR, Alpena Fishery Research Station); E. Braun, A. Grier, M. Burlingame, and S. Sheldon (Indiana DNR); D. Einhouse, W. Pearsall, J. Evans, and S. Cornett (New York State Department of Environmental Conservation); K. Kayle, J. Deller, C. Knight, T. Bader (Ohio Division of Wildlife (ODW), Fairport Harbor Unit); R. Knight, J. Tyson, and G. Emond (ODW, Sandusky Unit); M. Greenlee (ODW); B. Crump and R. Standage (Ouachita National Forest); B. Zawiski and S. Taylor (Ohio Environmental Protection Agency); M. Austin (Ohio Department of Transportation); R. Stein (Ohio State University); R. Butryn and R. Gonser (Indiana State University); G. Steinhart (Lake Superior State University); A. Echelle (Oklahoma State University); M. Coburn and L. Kousa (John Carroll University); R. Draper (The Ohio Smallmouth Alliance); B. Whiting (Trust Lands Office); M. Sabaj Perez (Academy of Natural Sciences, Philadelphia); B. Kuhajda (University of Alabama Ichthyological Collection); T. Bowens, B. Dunagan, A. Ford, J. Giboney, J. Holt, M. Jedlicka, D. Kiss, O. Lockhart, M. Lyons, T. Marth, and A. Thomas (Cleveland State University); J. Graham; P. and C. Hughes; C. Landreville; and M. Smith. P. Doerder (Cleveland State University (CSU)) designed new primers, and C. Li (University of Nebraska-Lincoln) provided analytical insight. Financial support was provided by the Department of Biological, Geological and Environmental Sciences and the College of Science (CSU), Ohio Sea Grant R/RL-5 (C. Stepien, University of Toledo), Doctoral Research Expense Award to W.C.B., and personal funds. This manuscript greatly benefited from thorough and constructive critiques from the associate editor and two anonymous referees. On a more personal note, we dedicate this work to Miles Coburn, co-advisor of W.C.B.'s dissertation research, who unexpectedly passed away in August 2008.

\section{References}

Bailey, R.M., and Smith, G.R. 1981. Origin and geography of the fish fauna of the Laurentian Great Lakes Basin. Can. J. Fish. Aquat. Sci. 38(12): 1539-1561. doi:10.1139/f81-206.

Berendzen, P.B., Simons, A.M., and Wood, R.M. 2003. Phylogeography of the northern hogsucker, Hypentelium nigricans (Teleostei: Cypriniformes): genetic evidence for the existence of the ancient Teays River. J. Biogeogr. 30(8): 1139-1152. doi:10. 1046/j.1365-2699.2003.00888.x.

Berendzen, P.B., Simons, A.M., Wood, R.M., Dowling, T.E., and Secor, C.L. 2008. Recovering cryptic diversity and ancient drainage patterns in eastern North America: historical biogeography of the Notropis rubellus species group (Teleostei: Cypriniformes). Mol. Phylogenet. Evol. 46(2): 721-737. doi:10.1016/j. ympev.2007.07.008. PMID:17716926.

Bernatchez, L., and Wilson, C.C. 1998. Comparative phylogeography of Nearctic and Palearctic fishes. Mol. Ecol. 7(4): 431-452. doi:10.1046/j.1365-294x.1998.00319.x.

Borden, W.C. 2008a. Assessment of genetic divergence between lacustrine and riverine smallmouth bass in Lake Erie and four tributaries. Northeast. Nat. 15(3): 335-348. doi:10.1656/10926194-15.3.335.

Borden, W.C. 2008b. Phylogeography of smallmouth bass (Micropterus dolomieu) and comparative myology of the black bass
(Micropterus, Centrarchidae). Ph.D. dissertation, Department of Biological, Geological and Environmental Sciences, Cleveland State University, Cleveland, Ohio.

Borden, W.C., and Stepien, C.A. 2006. Discordant population genetic structuring of smallmouth bass, Micropterus dolomieu Lacepède, in Lake Erie based on mitochondrial DNA sequences and nuclear DNA microsatellites. J. Great Lakes Res. 32(2): 242 257. doi:10.3394/0380-1330(2006)32[242:DPGSOS]2.0.CO;2.

Burr, B.M., and Page, L.M. 1986. Zoogeography of fishes of the lower Ohio-upper Mississippi basin. In The zoogeography of North American freshwater fishes. Edited by C.H. Hocutt and E.O. Wiley. John Wiley and Sons, New York. pp. 287-324.

Castelloe, J., and Templeton, A.R. 1994. Root probabilities for intraspecific gene trees under neutral coalescent theory. Mol. Phylogenet. Evol. 3(2): 102-113. doi:10.1006/mpev.1994.1013. PMID:8075830.

Clement, M., Posada, D., and Crandall, K.A. 2000. TCS: a computer program to estimate gene genealogies. Mol. Ecol. 9(10): 16571659. doi:10.1046/j.1365-294x.2000.01020.x. PMID:11050560.

Coughlin, W.D., Echelle, A.A., Van Den Bussche, R.A., Cofer, L.M., Fisher, W.L., and Propst, D.L. 2003. Genetic structure of spotted bass (Micropterus punctulatus) in the Red and Arkansas River basins: microsatellite and mitochondrial DNA variation. Southwest. Nat. 48(4): 526-533. doi:10.1894/0038-4909(2003) 048<0526:GSOSBM>2.0.CO;2.

Cowx, I.G., and Maldin, M.A. (Editors). 1998. Stocking and introduction of fish. Fishing News Books, Malden, Mass.

Cox, A.J., and Hebert, P.D.N. 2001. Colonization, extinction, and phylogeographic patterning in a freshwater crustacean. Mol. Ecol. 10(2): 371-386. doi:10.1046/j.1365-294x.2001.01188.x. PMID:11298952.

Crandall, K.A. 1996. Multiple interspecies transmissions of human and simian T-cell leukemia/lymphoma virus type I sequences. Mol. Biol. Evol. 13(1): 115-131. PMID:8583886.

Dowling, T.E., Broughton, R.E., and DeMarais, B.D. 1997. Significant role for historical effects in the evolution of reproductive isolation: evidence from patterns of introgression between the cyprinid fishes, Luxilus cornutus and Luxilus chrysocephalus. Evolution, 51(5): 1574-1583. doi:10.2307/2411209.

Eddy, S., Tasker, R.C., and Underhill, J.C. 1972. Fishes of the Red River, Rainy River, and Lake of the Woods, Minnesota, with comments on the distribution of species in the Nelson River drainage. Univ. Minn., Occas. Pap. Bell Mus. Nat. Hist. No. 11.

Eschman, D.F., and Karrow, P.F. 1985. Huron basin glacial lakes: a review. Geol. Assoc. Can. Spec. Pap. 30: 79-93.

Etnier, D.A., and Starnes, W.C. 1993. The fishes of Tennessee. The Univesity of Tennessee Press, Knoxville, Tenn.

Excoffier, L., Laval, G., and Schneider, S. 2006. Arlequin ver. 3.1: an integrated software package for population genetics data analysis. Evol. Bioinform. Online, 1: 47-50.

Felsenstein, J. 1981. Evolutionary trees from DNA sequences: a maximum likelihood approach. J. Mol. Evol. 17(6): 368-376. doi:10.1007/BF01734359. PMID:7288891.

Felsenstein, J. 1985. Confidence limits on phylogenies: an approach using the bootstrap. Evolution, 39(4): 783-791. doi:10. 2307/2408678.

Fidlar, M.M. 1948. Physiography of the Lower Wabash Valley. Division of Geology, Indiana Dept. of Conservation, Bull. No. 2.

Fu, Y.-X. 1997. Statistical tests of neutrality of mutations against population growth, hitchhiking and background selection. Genetics, 147(2): 915-925. PMID:9335623.

Gach, M.H. 1996. Geographic variation in mitochondrial DNA and biogeography of Culaea inconstans (Gasterosteidae). Copeia, 1996(3): 563-575. doi:10.2307/1447520. 
Garrick, R.C., Dyer, R.J., Beheregaray, L.B., and Sunnucks, P. 2008. Babies and bathwater: a comment on the premature obituary for nested clade phylogeographical analysis. Mol. Ecol. 17(6): 1401-1403, discussion 1404. doi:10.1111/j.1365-294X. 2008.03675.x. PMID:18284568.

Gerking, S.D. 1947. The use of minor postglacial drainage connections by fishes in Indiana. Copeia, 1947(2): 89-91. doi:10.2307/ 1438638.

Goldthwait, R.P. 1991. The Teays Valley problem: a historical perspective. In Geology and hydrogeology of the Teays-Mahomet bedrock valley system. Edited by W.N. Melhorn and J.P. Kempton. Geological Society of America Special Paper No. 258, Boulder, Co. pp. 3-8.

Graf, D.L. 2002. Historical biogeography and late glacial origin of the freshwater pearly mussel (Bivalvia: Unionidae) faunas of Lake Erie, North America. Occas. Pap. Mollusks Mus. Comp. Zool. Harv. Univ. 6: 175-211.

Grant, W.S., and Bowen, B.W. 1998. Shallow population histories in deep evolutionary lineages of marine fishes: insights from sardines and anchovies and lessons for conservation. J. Hered. 89(5): 415-426. doi:10.1093/jhered/89.5.415.

Gray, H.H. 1991. Origin and history of the Teays drainage system: the view from midstream. In Geology and hydrogeology of the Teays-Mahomet bedrock valley system. Edited by W.N. Melhorn and J.P. Kempton. Geological Society of America Special Paper No. 258, Boulder, Co. pp. 43-50.

Hasegawa, M., Kishino, H., and Yano, T. 1985. Dating of the human-ape splitting by a molecular clock of mitochondrial DNA. J. Mol. Evol. 22(2): 160-174. doi:10.1007/BF02101694. PMID:3934395.

Hocutt, C.H., Denoncourt, R.F., and Stauffer, J.R., Jr. 1978. Fishes of the Greenbrier River, West Virginia, with drainage history of the Central Appalachians. J. Biogeogr. 5(1): 59-80. doi:10.2307/ 3038108.

Hocutt, C.H., Jenkins, R.E., and Stauffer, J.R., Jr. 1986. Zoogeography of the fishes of the Central Appalachians and Central Atlantic Coastal Plain. In The zoogeography of North American freshwater fishes. Edited by C.H. Hocutt and E.O. Wiley. John Wiley and Sons, New York. pp. 161-212.

Howard, J.H., and Morgan, R.P., II. 1993. Alloyme variation in the mottled sculpin (Cottus bairdi): a test of stream capture hypotheses. Copeia, 1993(3): 870-875. doi:10.2307/1447255.

Hubbs, C.L., and Bailey, R.M. 1940. A revision of the black basses (Micropterus and Huro) with descriptions of four new forms. Misc. Publ. Mus. Zool. Univ. Mich. No. 48.

Huelsenbeck, J.P., and Crandall, K.A. 1997. Phylogenetic estimation and hypothesis testing using maximum likelihood. Annu. Rev. Ecol. Syst. 28(1): 437-466. doi:10.1146/annurev.ecolsys. 28.1.437.

Huelsenbeck, J.P., and Ronquist, F. 2001. MRBAYES: Bayesian inference of phylogenetic trees. Bioinformatics, 17(8): 754-755. doi:10.1093/bioinformatics/17.8.754. PMID:11524383.

Jobb, G. 2008. TREEFINDER, version of October 2008. Munich, Germany. Distributed by the author at www.treefinder.de.

Klicka, J., and Zink, R.M. 1997. The importance of recent ice ages in speciation: a failed paradigm. Science (Washington, D.C.), 277(5332): 1666-1669. doi:10.1126/science.277.5332.1666.

Klicka, J., and Zink, R.M. 1998. Pleistocene speciation and the mitochondrial DNA clock: a response to Arbogast and Slowinski. Science (Washington, D.C.), 282(5396): 1955a-1955. doi:10. 1126/science.282.5396.1955a.

Knowles, L.L., and Maddison, W.P. 2002. Statistical phylogeography. Mol. Ecol. 11(12): 2623-2635. doi:10.1046/j.1365-294X. 2002.01637.x. PMID:12453245.
Koppelman, J.B., and Garrett, G.P. 2002. Distribution, biology, and conservation of the rare black bass species. In Black bass: ecology, conservation, and management. Edited by D.P. Philipp and M.S. Ridgway. AFS Symposium No. 31, American Fisheries Society, Bethesda, Md. pp. 333-341.

Kozak, K.H., Blaine, R.A., and Larson, A. 2006. Gene lineages and eastern North American palaeodrainage basins: phylogeography and speciation in salamanders of the Eurycea bislineata species complex. Mol. Ecol. 15(1): 191-207. doi:10.1111/j.1365-294X. 2005.02757.x. PMID:16367840.

Lanave, C., Preparata, G., Saccone, C., and Serio, G. 1984. A new method for calculating evolutionary substitution rates. J. Mol. Evol. 20(1): 86-93. doi:10.1007/BF02101990. PMID:6429346.

Mandrak, N.E., and Crossman, E.J. 1992. Postglacial dispersal of freshwater fishes into Ontario. Can. J. Zool. 70(11): 2247-2259. doi:10.1139/z92-302.

Mayden, R.L. 1985. Biogeography of Ouachita Highland fishes. Southwest. Nat. 30(2): 195-211. doi:10.2307/3670734.

Mayden, R.L. 1987. Historical ecology and North American Highland fishes: a research program in community ecology. In Community and evolutionary ecology of North American stream fishes. Edited by W.J. Matthews and D.C. Heins. University of Oklahoma Press, Norman, Okla. pp. 210-222.

Melhorn, W.N., and Kempton, J.P. 1991. The Teays System: a summary. In Geology and hydrogeology of the Teays-Mahomet bedrock valley system. Edited by W.N. Melhorn and J.P. Kempton. Geological Society of America Special Paper No. 258, Boulder, Co. pp. 125-128.

Morrison, C.L., Lemarié, D.P., Wood, R.M., and King, T.L. 2006. Phylogeographic analyses suggest multiple lineages of Crystallaria asprella (Percidae, Etheostominae). Conserv. Genet. 7(1): 129-147. doi:10.1007/s10592-005-5681-8.

Murdoch, M.H., and Hebert, P.D.N. 1997. Mitochondrial DNA evidence of distinct glacial refugia for brown bullhead (Ameiurus nebulosus) in the Great Lakes. Can. J. Fish. Aquat. Sci. 54(7): 1450-1460. doi:10.1139/cjfas-54-7-1450.

Near, T.J., Kassler, T.W., Koppelman, J.B., Dillman, C.B., and Philipp, D.P. 2003. Speciation in North American black basses, $\mathrm{Mi}$ cropterus (Actinopterygii: Centrarchidae). Evolution, 57(7): 1610-1621. PMID:12940365.

Near, T.J., Bolnick, D.I., and Wainwright, P.C. 2005. Fossil calibrations and molecular divergence time estimates in centrarchid fishes (Teleostei: Centrarchidae). Evolution, 59(8): 1768-1782. PMID:16329246.

Nylander, J.A.A. 2004. MrModeltest v 2. Program distributed by the author. Evolutionary Biology Centre, Uppsala University, Uppsala, Sweden.

Page, L.M., and Burr, B.M. 1991. Freshwater fishes. Houghton Mifflin Company, New York.

Panchal, M. 2006. The automation of nested clade phylogeographic analysis. Bioinformatics, 23(4): 509-510. doi:10.1093/ bioinformatics/btl614. PMID:17142814.

Panchal, M., and Beaumont, M.A. 2007. The automation and evaluation of nested clade phylogeographic analysis. Evolution, 61(6): 1466-1480. doi:10.1111/j.1558-5646.2007.00124.x. PMID: 17542853.

Petit, R.J. 2008. The coup de grâce for the nested clade phylogeographic analysis? Mol. Ecol. 17(2): 516-518. PMID:17956540.

Péwé, T.L. 1983. The periglacial environment in North America during Wisconsin time. In Late-quaternary environments of the United States. Edited by H.E. Wright, Jr. Of the series The Late Pleistocene. Vol. 1. Series edited by S.C. Porter. University of Minnesota Press, Minneapolis, Minn. pp. 157-189.

Placyk, J.S., Jr., Burghardt, G.M., Small, R.L., King, R.B., Casper, 
G.S., and Robinson, J.W. 2007. Post-glacial recolonization of the Great Lakes region by the common gartersnake (Thamnophis sirtalis) inferred from mtDNA sequences. Mol. Phylogenet. Evol. 43(2): 452-467. doi:10.1016/j.ympev.2006.10.023. PMID: 17174111.

Posada, D., and Buckley, T.R. 2004. Model selection and model averaging in phylogenetics: advantages of the Akaike Information Criterion and Bayesian approaches over likelihood ratio tests. Syst. Biol. 53(5): 793-808. doi:10.1080/ 10635150490522304 . PMID:15545256.

Posada, D., and Crandall, K.A. 2001. Intraspecific gene genealogies: trees grafting into networks. Trends Ecol. Evol. 16(1): 3745. doi:10.1016/S0169-5347(00)02026-7. PMID:11146143.

Posada, D., Crandall, K.A., and Templeton, A.R. 2000. GeoDis: a program for the cladistic nested analysis of the geographical distribution of genetic haplotypes. Mol. Ecol. 9(4): 487-488. doi:10.1046/j.1365-294x.2000.00887.x. PMID:10736051.

Ray, J.M., Wood, R.M., and Simons, A.M. 2006. Phylogeography and post-glacial colonization patterns of the rainbow darter, Etheostoma caeruleum (Teleostei: Percidae). J. Biogeogr. 33(9): 1550-1558. doi:10.1111/j.1365-2699.2006.01540.x.

Ridgway, M.S., Shuter, B., and Post, E.E. 1991. The relative influence of body size and territorial behaviour on nesting asynchrony in male smallmouth bass, Micropterus dolomieu (Pisces: Centrarchidae). J. Anim. Ecol. 60(2): 665-681. doi:10.2307/5304.

Ridgway, M.S., Shuter, B., Middel, T.A., and Gross, M.L. 2002. Spatial ecology and density-dependent processes in smallmouth bass: the juvenile transition hypothesis. In Black bass: ecology, conservation, and management. Edited by D.P. Philipp and M.S. Ridgway. American Fisheries Society Symposium No. 31, American Fisheries Society, Bethesda, Md. pp. 47-60.

Robison, H.W., and Buchanan, T.M. 1988. Fishes of Arkansas. The University of Arkansas Press, Fayetteville, Ark.

Rogers, A.R., and Harpending, H. 1992. Population growth makes waves in the distribution of pairwise genetic differences. Mol. Biol. Evol. 9(3): 552-569. PMID:1316531.

Ronquist, F., and Huelsenbeck, J.P. 2003. MrBayes 3: Bayesian phylogenetic inference under mixed models. Bioinformatics, 19(12): 1572-1574. doi:10.1093/bioinformatics/btg180. PMID: 12912839.

Rousset, F. 1997. Genetic differentiation and estimation of gene flow from $F$-statistics under isolation by distance. Genetics, 145(4): 1219-1228. PMID:9093870.

Rubec, P.J. 1975. Fish distribution in Gatineau Park, Quebec, in relation to postglacial dispersal, man's influence, and eutrophication. Can. Field Nat. 89: 389-399.

Schneider, S., and Excoffier, L. 1999. Estimation of past demographic parameters from the distribution of pairwise differences when the mutation rates vary among sites: application to human mitochondrial DNA. Genetics, 152(3): 1079-1089. PMID: 10388826.

Scott, W.B., and Crossman, E.J. 1973. Freshwater fishes of Canada. Bull. Fish. Res. Board Can. No. 184.

Stark, W.J., and Echelle, A.A. 1998. Genetic structure and systematics of smallmouth bass, with emphasis on Interior Highlands populations. Trans. Am. Fish. Soc. 127(3): 393-416. doi:10.1577/1548-8659(1998)127<0393:GSASOS>2.0.CO;2.

Starnes, W.C., and Etnier, D.A. 1986. Drainage evolution and fish biogeography of the Tennessee and Cumberland rivers drainage realm. In The zoogeography of North American freshwater fishes. Edited by C.H. Hocutt and E.O. Wiley. John Wiley and Sons, New York. pp. 325-361.

Stepien, C.A., Murphy, D.J., and Strange, R.M. 2007. Broad- to fine-scale population genetic patterning in the smallmouth bass
Micropterus dolomieu across the Laurentian Great Lakes and beyond: an interplay of behaviour and geography. Mol. Ecol. 16(8): 1605-1624. doi:10.1111/j.1365-294X.2006.03168.x. PMID: 17402977.

Strange, R.M., and Burr, B.M. 1997. Intraspecific phylogeography of North American Highland fishes: a test of the Pleistocene vicariance hypothesis. Evolution, 51(3): 885-897. doi:10.2307/ 2411163.

Swenson, N.G., and Howard, D.J. 2005. Clustering of contact zones, hybrid zones, and phylogeographic breaks in North America. Am. Nat. 166(5): 581-591. doi:10.1086/491688. PMID:16224723.

Swofford, D.L. 1998. PAUP*v4b10. Phylogenetic Analysis Using Parsimony (*and Other Methods). Sinauer Associates, Sunderland, Mass.

Teller, J.T. 1973. Preglacial (Teays) and early glacial drainages in the Cincinnati area, Ohio, Kentucky, and Indiana. Bull. Geol. Soc. Am. 84(11): 3677-3688. doi:10.1130/0016-7606(1973) 84<3677:PTAEGD>2.0.CO;2.

Teller, J.T. 2004. Controls, history, outbursts, and impact of large late-Quaternary proglacial lakes in North America. In The Quaternary Period in the United States. Edited by A.R. Gillespie, S.C. Porter, and B.F. Atwater. Of the series Developments in Quaternary Science. Series edited by J. Rose. Elsevier, New York. pp. 45-61.

Templeton, A.R. 2002. Out of Africa again and again. Nature (London), 416(6876): 45-51. doi:10.1038/416045a. PMID:11882887.

Templeton, A.R. 2004. Statistical phylogeography: methods of evaluating and minimizing inference errors. Mol. Ecol. 13(4): 789809. doi:10.1046/j.1365-294X.2003.02041.x. PMID:15012756.

Templeton, A.R. 2008. Nested clade analysis: an extensively validated method for strong phylogeographic inference. Mol. Ecol. 17(8): 1877-1880. doi:10.1111/j.1365-294X.2008.03731.x. PMID:18346121.

Templeton, A.R., Boerwinkle, E., and Sing, C.F. 1987. A cladistic analysis of phenotypic associations with haplotypes inferred from restriction endonuclease mapping. I. Basic theory and an analysis of alcohol dehydrogenase activity in Drosophila. Genetics, 117(2): 343-351. PMID:2822535.

Templeton, A.R., Routman, E., and Phillips, C.A. 1995. Separating population structure from population history: a cladistic analysis of the geographical distribution of mitochondrial DNA haplotypes in the tiger salamander, Ambystoma tigrinum. Genetics, 140(2): 767-782. PMID:7498753.

Trautman, M.B. 1981. The fishes of Ohio. Revised ed. Ohio State University Press, Columbus, Ohio.

Underhill, J.C. 1986. The fish fauna of the Laurentian Great Lakes, the St. Lawrence lowlands, Newfoundland and Labrador. In The zoogeography of North American freshwater fishes. Edited by C.H. Hocutt and E.O. Wiley. John Wiley and Sons, New York. pp. 105-136.

Ware, D.M. 1978. Bioenergetics of pelagic fish: theoretical changes in swimming speed and ration with body size. J. Fish. Res. Board Can. 35: 220-228.

Wayne, W.J. 1952. Pleistocene evolution of the Ohio and Wabash valleys. J. Geol. 60(6): 575-585. doi:10.1086/626023.

Wiley, E.O., and Mayden, R.L. 1985. Species and speciation in phylogenetic systematics, with examples from the North American fish fauna. Ann. Mo. Bot. Gard. 72(4): 596-635. doi:10. 2307/2399217.

Wilson, C.C., and Hebert, P.D.N. 1998. Phylogeography and postglacial dispersal of lake trout (Salvelinus namaycush) in North America. Can. J. Fish. Aquat. Sci. 55(4): 1010-1024. doi:10. 1139/cjfas-55-4-1010. 


\section{Appendix A}

Table A1. Localities, sample sizes, and diversity indices ( $h$, haplotype; $\pi$, nucleotide $\times 100)$, with standard errors $(\operatorname{SE}(h) \times 100$, $\left.\mathrm{SE}(\pi) \times 10^{4}\right)$ in parentheses.

\begin{tabular}{|c|c|c|c|c|c|c|c|}
\hline $\begin{array}{l}\text { Site } \\
\text { No. }\end{array}$ & & $\begin{array}{l}\text { Latitude } \\
(\mathrm{N})\end{array}$ & $\begin{array}{l}\text { Longitude } \\
\text { (W) }\end{array}$ & $n$ & $n H$ & $h$ & $\pi$ \\
\hline & Great Lakes Basin & & & 278 & 26 & $0.96(<0.01)$ & $0.31(0.11)$ \\
\hline & Lake Superior & & & 21 & 4 & $0.47(0.57)$ & $0.25(0.76)$ \\
\hline 1 & Pigeon River, Minn. & $48^{\circ} 00^{\prime}$ & $89^{\circ} 35^{\prime}$ & 2 & 1 & & \\
\hline 2 & St. Louis Bay, Minn. & $46^{\circ} 43^{\prime}$ & $92^{\circ} 09^{\prime}$ & 2 & 1 & & \\
\hline 3 & Spirit Lake, Minn. & $46^{\circ} 41^{\prime}$ & $92^{\circ} 12^{\prime}$ & 14 & 3 & & \\
\hline \multirow[t]{2}{*}{4} & Tahquamenon River, Mich. & $46^{\circ} 34^{\prime}$ & $85^{\circ} 02^{\prime}$ & 3 & 2 & & \\
\hline & Lake Michigan & & & 25 & 4 & $0.63(0.32)$ & $0.20(0.56)$ \\
\hline 5 & Milwaukee River, Wis. & $43^{\circ} 02^{\prime}$ & $87^{\circ} 56^{\prime}$ & 12 & 3 & & \\
\hline 6 & Port Washington Harbor, Wis. & $43^{\circ} 23^{\prime}$ & $87^{\circ} 53^{\prime}$ & 4 & 1 & & \\
\hline \multirow[t]{3}{*}{7} & Sheyboygan River, Wis. & $43^{\circ} 45^{\prime}$ & $87^{\circ} 43^{\prime}$ & 9 & 2 & & \\
\hline & Lake Huron & & & 49 & 9 & $0.84(0.06)$ & $0.31(0.39)$ \\
\hline & Georgian Bay & & & 10 & 2 & $0.36(1.60)$ & $0.04(0.50)$ \\
\hline 8 & Blackstone Harbor, Ont. & $45^{\circ} 10^{\prime}$ & $79^{\circ} 59^{\prime}$ & 2 & 1 & & \\
\hline 9 & Midland Bay, Ont. & $44^{\circ} 45^{\prime}$ & $79^{\circ} 53^{\prime}$ & - & - & & \\
\hline 10 & Moon River, Ont. & $45^{\circ} 07^{\prime}$ & $79^{\circ} 57^{\prime}$ & 5 & 1 & & \\
\hline 11 & Severn Locks, Ont. & $44^{\circ} 48^{\prime}$ & $79^{\circ} 44^{\prime}$ & 1 & 1 & & \\
\hline 12 & Severn Sound, Ont. & $44^{\circ} 47^{\prime}$ & $79^{\circ} 44^{\prime}$ & 2 & 1 & & \\
\hline 13 & Maitland River, Ont. & $44^{\circ} 34^{\prime}$ & $80^{\circ} 56^{\prime}$ & - & - & & \\
\hline \multirow[t]{4}{*}{14} & Les Cheneaux Islands & & & 3 & 1 & - & - \\
\hline & Goat Island, Mich. & $46^{\circ} 00^{\prime}$ & $84^{\circ} 26^{\prime}$ & 1 & 1 & & \\
\hline & Haven Island, Mich. & $46^{\circ} 00^{\prime}$ & $84^{\circ} 25^{\prime}$ & 1 & 1 & & \\
\hline & Musky Bay East, Mich. & $45^{\circ} 58^{\prime}$ & $84^{\circ} 21^{\prime}$ & 1 & 1 & & \\
\hline \multirow[t]{4}{*}{15} & Potagannissing Bay & & & 2 & 2 & $1.00(0.25)$ & $0.36(20.62)$ \\
\hline & Black Rock Point, Mich. & $46^{\circ} 00^{\prime}$ & $83^{\circ} 52^{\prime}$ & 1 & 1 & & \\
\hline & Grape Island, Mich. & $46^{\circ} 02^{\prime}$ & $83^{\circ} 44^{\prime}$ & 1 & 1 & & \\
\hline & Saginaw Bay & & & 13 & 5 & $0.70(0.92)$ & $0.19(1.02)$ \\
\hline 16 & Charity Island, Mich. & $44^{\circ} 16^{\prime}$ & $83^{\circ} 29^{\prime}$ & 1 & 1 & & \\
\hline 17 & Oak Point North, Mich. & $43^{\circ} 59^{\prime}$ & $83^{\circ} 17^{\prime}$ & 4 & 3 & & \\
\hline 18 & Saginaw River, Mich. & $43^{\circ} 29^{\prime}$ & $83^{\circ} 55^{\prime}$ & 5 & 4 & & \\
\hline \multirow[t]{2}{*}{19} & Tittabawassee River, Mich. & $43^{\circ} 41^{\prime}$ & $84^{\circ} 23^{\prime}$ & 3 & 1 & & \\
\hline & Thunder Bay & & & & & & \\
\hline \multirow[t]{2}{*}{20} & Thunder Bay, Mich. & $45^{\circ} 01^{\prime}$ & $83^{\circ} 26^{\prime}$ & 21 & 3 & $0.41(0.57)$ & $0.24(0.74)$ \\
\hline & Lake Erie & & & 161 & 20 & $0.91(<0.01)$ & $0.27(0.11)$ \\
\hline 21 & Ashtabula, Ohio & $41^{\circ} 55^{\prime}$ & $80^{\circ} 49^{\prime}$ & 8 & 5 & & \\
\hline 22 & Bass Islands, Ohio & $41^{\circ} 41^{\prime}$ & $82^{\circ} 49^{\prime}$ & 7 & 2 & & \\
\hline 23 & Conneaut, Ohio & $41^{\circ} 58^{\prime}$ & $80^{\circ} 33^{\prime}$ & 8 & 5 & & \\
\hline 24 & Fairport Harbor, Ohio & $41^{\circ} 46^{\prime}$ & $81^{\circ} 16^{\prime}$ & 6 & 4 & & \\
\hline 25 & Gem Beach, Ohio & $41^{\circ} 34^{\prime}$ & $82^{\circ} 49^{\prime}$ & 11 & 4 & & \\
\hline 26 & Long Point Bay, Ont. & $42^{\circ} 38^{\prime}$ & $80^{\circ} 19^{\prime}$ & 9 & 6 & & \\
\hline 27 & Perry, Ohio & $41^{\circ} 48^{\prime}$ & $81^{\circ} 10^{\prime}$ & 8 & 3 & & \\
\hline 28 & Port Clinton, Ohio & $41^{\circ} 31^{\prime}$ & $82^{\circ} 56^{\prime}$ & 10 & 5 & & \\
\hline 29 & Sandusky Bay, Ohio & $41^{\circ} 30^{\prime}$ & $82^{\circ} 44^{\prime}$ & 9 & 4 & & \\
\hline 30 & Van Buren Bay, N.Y. & $42^{\circ} 27^{\prime}$ & $79^{\circ} 24^{\prime}$ & 10 & 6 & & \\
\hline 31 & Auglaize River, Ohio & $40^{\circ} 37^{\prime}$ & $84^{\circ} 15^{\prime}$ & 8 & 4 & & \\
\hline 32 & Blanchard River, Ohio & $40^{\circ} 46^{\prime}$ & $83^{\circ} 34^{\prime}$ & 5 & 2 & & \\
\hline 33 & Black River, Ohio & $41^{\circ} 06^{\prime}$ & $82^{\circ} 06^{\prime}$ & 5 & 3 & & \\
\hline 34 & Cattaraugus Creek, N.Y. & $42^{\circ} 34^{\prime}$ & $79^{\circ} 06^{\prime}$ & 11 & 7 & & \\
\hline 35 & Chagrin River, Ohio & $41^{\circ} 29^{\prime}$ & $81^{\circ} 23^{\prime}$ & 19 & 3 & & \\
\hline 36 & Conneaut Creek, Ohio & $41^{\circ} 54^{\prime}$ & $80^{\circ} 32^{\prime}$ & 2 & 1 & & \\
\hline 37 & Cuyahoga River, Ohio & $41^{\circ} 08^{\prime}$ & $81^{\circ} 24^{\prime}$ & 10 & 5 & & \\
\hline 38 & Grand River, Ohio & $41^{\circ} 44^{\prime}$ & $81^{\circ} 00^{\prime}$ & 12 & 5 & & \\
\hline 39 & Rocky River, Ohio & $41^{\circ} 25^{\prime}$ & $81^{\circ} 53^{\prime}$ & 3 & 2 & & \\
\hline
\end{tabular}


Table A1 (concluded).

\begin{tabular}{|c|c|c|c|c|c|c|c|}
\hline $\begin{array}{l}\text { Site } \\
\text { No. }\end{array}$ & & $\begin{array}{l}\text { Latitude } \\
(\mathrm{N})\end{array}$ & $\begin{array}{l}\text { Longitude } \\
\text { (W) }\end{array}$ & $n$ & $n H$ & $h$ & $\pi$ \\
\hline & Lake Ontario & & & 18 & 2 & $0.47(0.44)$ & $0.17(0.67)$ \\
\hline 40 & Bay of Quinte, Ont. & $44^{\circ} 06^{\prime}$ & $77^{\circ} 11^{\prime}$ & 11 & 1 & & \\
\hline 41 & Pultneyville, N.Y. & $43^{\circ} 17^{\prime}$ & $77^{\circ} 08^{\prime}$ & 1 & 1 & & \\
\hline \multirow[t]{2}{*}{42} & Rushford Lake, N.Y. & $42^{\circ} 23^{\prime}$ & $78^{\circ} 12^{\prime}$ & 6 & 1 & & \\
\hline & St. Lawrence River & & & 4 & 1 & - & - \\
\hline 43 & Cranberry Lake, N.Y. & $44^{\circ} 10^{\prime}$ & $74^{\circ} 49^{\prime}$ & 2 & 1 & & \\
\hline 44 & Lac Bernard, Que. & $45^{\circ} 45^{\prime}$ & $75^{\circ} 58^{\prime}$ & 1 & 1 & & \\
\hline \multirow[t]{3}{*}{45} & Lac des Trente-et-un-Milles, Que. & $46^{\circ} 10^{\prime}$ & $75^{\circ} 49^{\prime}$ & 1 & 1 & & \\
\hline & Mississippi River Basin & & & 137 & 28 & $0.95(<0.01)$ & $0.39(0.16)$ \\
\hline & Mississippi River & & & 24 & 3 & $0.24(0.46)$ & $0.10(0.33)$ \\
\hline 46 & Apple River, Wis. & $45^{\circ} 08^{\prime}$ & $92^{\circ} 40^{\prime}$ & 8 & 1 & & \\
\hline 47 & Cannon River, Minn. & $44^{\circ} 31^{\prime}$ & $92^{\circ} 53^{\prime}$ & 5 & 2 & & \\
\hline 48 & Mississippi River, Minn. & $44^{\circ} 39^{\prime}$ & $92^{\circ} 40^{\prime}$ & - & - & & \\
\hline 49 & North Fork Crow River, Minn. & $45^{\circ} 23^{\prime}$ & $94^{\circ} 47^{\prime}$ & 1 & 1 & & \\
\hline 50 & St. Croix River, Minn. & $45^{\circ} 13^{\prime}$ & $92^{\circ} 45^{\prime}$ & 7 & 1 & & \\
\hline \multirow[t]{2}{*}{51} & Zumbro River, Minn. & $44^{\circ} 13^{\prime}$ & $92^{\circ} 28^{\prime}$ & 3 & 1 & & \\
\hline & Illinois River & & & 21 & 3 & $0.40(0.52)$ & $0.05(0.24)$ \\
\hline 52 & Crow Creek, Ill. & $40^{\circ} 57^{\prime}$ & $89^{\circ} 19^{\prime}$ & 9 & 2 & & \\
\hline 53 & Mackinaw River, Ill. & $40^{\circ} 37^{\prime}$ & $89^{\circ} 15^{\prime}$ & 3 & 1 & & \\
\hline 54 & Rooks Creek, Ill. & $40^{\circ} 52^{\prime}$ & $88^{\circ} 43^{\prime}$ & 6 & 2 & & \\
\hline \multirow[t]{3}{*}{55} & Vermilion River, Ill. & $41^{\circ} 15^{\prime}$ & $89^{\circ} 00^{\prime}$ & 3 & 1 & & \\
\hline & Ohio River & & & 81 & 20 & $0.96(0.09)$ & $0.31(0.23)$ \\
\hline & Allegheny River & & & & & & \\
\hline \multirow[t]{2}{*}{56} & Lake Chautauqua, N.Y. & $42^{\circ} 11^{\prime}$ & $79^{\circ} 26^{\prime}$ & 11 & 4 & $0.60(1.36)$ & $0.16(1.09)$ \\
\hline & $\begin{array}{l}\text { Ohio River: north shore, primarily gla- } \\
\text { ciated }\end{array}$ & & & 20 & 7 & $0.83(0.25)$ & $0.22(0.75)$ \\
\hline 57 & Big Darby Creek, Ohio & $40^{\circ} 11^{\prime}$ & $83^{\circ} 26^{\prime}$ & 1 & 1 & & \\
\hline 58 & Hocking River, Ohio & $39^{\circ} 35^{\prime}$ & $82^{\circ} 29^{\prime}$ & 5 & 2 & & \\
\hline 59 & Paint Creek, Ohio & $39^{\circ} 19^{\prime}$ & $83^{\circ} 04^{\prime}$ & 1 & 1 & & \\
\hline 60 & Paw Paw Creek, Ohio & $39^{\circ} 33^{\prime}$ & $81^{\circ} 20^{\prime}$ & 5 & 3 & & \\
\hline \multirow[t]{2}{*}{61} & Walhonding River, Ohio & $40^{\circ} 20^{\prime}$ & $82^{\circ} 00^{\prime}$ & 8 & 5 & & \\
\hline & Ohio River: south shore, unglaciated & & & 18 & 8 & $0.86(0.33)$ & $0.46(1.50)$ \\
\hline 62 & Greenbrier River, West Virginia & $37^{\circ} 44^{\prime}$ & $80^{\circ} 32^{\prime}$ & 10 & 6 & & \\
\hline \multirow[t]{2}{*}{63} & New River, Virginia & $36^{\circ} 55^{\prime}$ & $80^{\circ} 48^{\prime}$ & 8 & 3 & & \\
\hline & Wabash River & & & 32 & 11 & $0.91(0.06)$ & $0.30(0.56)$ \\
\hline 64 & Rock Creek, Ind. & $40^{\circ} 48^{\prime}$ & $85^{\circ} 21^{\prime}$ & 13 & 4 & & \\
\hline \multirow[t]{2}{*}{65} & Salt Fork River, Ill. & $40^{\circ} 06^{\prime}$ & $87^{\circ} 49^{\prime}$ & 19 & 9 & & \\
\hline & $\begin{array}{l}\text { Red River } \\
\text { Little River }\end{array}$ & & & 9 & 4 & $0.78(1.22)$ & $0.42(3.00)$ \\
\hline \multirow[t]{2}{*}{66} & Brushy Creek, Ark. & $34^{\circ} 24^{\prime}$ & $94^{\circ} 14^{\prime}$ & 5 & 2 & $0.40(4.75)$ & $0.14(2.53)$ \\
\hline & Ouachita River & & & 4 & 2 & $0.67(5.10)$ & $0.016(3.64)$ \\
\hline 67 & Board Camp Creek, Ark. & $34^{\circ} 32^{\prime}$ & $94^{\circ} 06^{\prime}$ & 3 & 2 & & \\
\hline \multirow[t]{2}{*}{68} & Gap Creek, Ark. & $34^{\circ} 29^{\prime}$ & $94^{\circ} 08^{\prime}$ & 1 & 1 & & \\
\hline & $\begin{array}{l}\text { Arkansas River } \\
\text { Illinois River }\end{array}$ & & & & & & \\
\hline \multirow[t]{2}{*}{69} & $\begin{array}{l}\text { Baron Fork Creek, Okla. } \\
\text { Atlantic Ocean }\end{array}$ & $35^{\circ} 57^{\prime}$ & $94^{\circ} 49^{\prime}$ & 2 & 1 & - & - \\
\hline & James River & & & 12 & 2 & $0.17(1.08)$ & $0.14(0.92)$ \\
\hline 70 & Cowpasture River, Va. & $37^{\circ} 50^{\prime}$ & $79^{\circ} 44^{\prime}$ & 3 & 1 & & \\
\hline \multirow[t]{2}{*}{71} & James River, Va. & $37^{\circ} 46^{\prime}$ & $79^{\circ} 48^{\prime}$ & 9 & 2 & & \\
\hline & Total & & & 427 & 45 & $0.88(<0.01)$ & $0.35(0.05)$ \\
\hline
\end{tabular}

Note: The Ohio River is partitioned into upper, middle, and lower reaches reflecting its variable geological history. Site numbers correspond to Fig. 1. 


\section{Appendix B}

Table B1. Unique composite mtDNA haplotypes, their component sequences, and GenBank accession numbers.

\begin{tabular}{|c|c|c|c|c|}
\hline $\begin{array}{l}\text { Concatenated } \\
\text { haplotype ID }\end{array}$ & $\begin{array}{l}\text { Cytochrome } b \\
\text { haplotype ID }\end{array}$ & $\begin{array}{l}\text { GenBank } \\
\text { accession no. }\end{array}$ & $\begin{array}{l}\text { Control haplotype } \\
\text { ID }\end{array}$ & $\begin{array}{l}\text { GenBank accession } \\
\text { no. }\end{array}$ \\
\hline A & 1 & DQ 354383 & 11 & EU 267709 \\
\hline $\mathrm{B}$ & 2 & DQ 354384 & 10 & EU 267708 \\
\hline $\mathrm{C}$ & 6 & EU 267711 & 3 & DQ 354377 \\
\hline $\mathrm{D}$ & 1 & & 3 & \\
\hline $\mathrm{E}$ & 7 & EU 267712 & 3 & \\
\hline $\mathrm{F}$ & 1 & & 4 & DQ 354378 \\
\hline $\mathrm{G}$ & 1 & & 2 & DQ 354376 \\
\hline $\mathrm{H}$ & 1 & & 1 & DQ 354375 \\
\hline I & 1 & & 7 & DQ 354381 \\
\hline J & 2 & & 1 & \\
\hline $\mathrm{K}$ & 4 & DQ 354386 & 1 & \\
\hline $\mathrm{L}$ & 1 & & 12 & EU 267710 \\
\hline M & 8 & EU 267713 & 1 & \\
\hline $\mathrm{N}$ & 5 & DQ 354387 & 1 & \\
\hline $\mathrm{O}$ & 5 & & 9 & EU 267707 \\
\hline $\mathrm{P}$ & 5 & & 5 & DQ 354379 \\
\hline Q & 16 & EU 639393 & 3 & \\
\hline $\mathrm{R}$ & 3 & DQ 354385 & 1 & \\
\hline S & 16 & & 1 & \\
\hline $\mathrm{T}$ & 15 & EU 639392 & 1 & \\
\hline $\mathrm{U}$ & 2 & & 4 & \\
\hline V & 1 & & 13 & EU 639379 \\
\hline W & 1 & & 15 & EU 639381 \\
\hline $\mathrm{X}$ & 1 & & 14 & EU 639380 \\
\hline $\mathrm{Y}$ & 1 & & 20 & EU 639386 \\
\hline $\mathrm{Z}$ & 1 & & 18 & EU 639384 \\
\hline AA & 1 & & 16 & EU 639382 \\
\hline BB & 13 & EU 639391 & 3 & \\
\hline $\mathrm{CC}$ & 9 & EU 639403 & 3 & \\
\hline $\mathrm{DD}$ & 19 & EU 639396 & 3 & \\
\hline $\mathrm{EE}$ & 6 & & 11 & \\
\hline $\mathrm{FF}$ & 17 & EU 639394 & 3 & \\
\hline GG & 20 & EU 639397 & 3 & \\
\hline $\mathrm{HH}$ & 1 & & 8 & DQ 354382 \\
\hline II & 1 & & 10 & \\
\hline JJ & 1 & & 6 & DQ 354380 \\
\hline KK & 21 & EU 639398 & 1 & \\
\hline LL & 11 & EU 639390 & 1 & \\
\hline MM & 11 & & 6 & \\
\hline NN & 14 & EU 639400 & 3 & \\
\hline $\mathrm{OO}$ & 12 & EU 639401 & 3 & \\
\hline $\mathrm{PP}$ & 22 & EU 639399 & 11 & \\
\hline QQ & 10 & EU 639402 & 3 & \\
\hline $\mathrm{RR}$ & 10 & & 21 & EU 639387 \\
\hline SS & 18 & EU 639395 & 19 & EU 639385 \\
\hline AAC 11 & Spotted bass & EU 639405 & Spotted bass & EU 639389 \\
\hline INHS 52356, UAIC 12771.15 & Spotted bass & FJ 595993 & Spotted bass & FJ 595994 \\
\hline BLC 4 & Largemouth bass & EU 639404 & Largemouth bass & EU 639388 \\
\hline
\end{tabular}

Note: Identification labels are consistent with those in Borden and Stepien (2006) and Borden (2008a, 2008b).

\section{References}

Borden, W.C. 2008a. Assessment of genetic divergence between lacustrine and riverine smallmouth bass in Lake Erie and four tributaries. Northeast. Nat. 15(3): 335-348. doi:10.1656/10926194-15.3.335.

Borden, W.C. 2008b. Phylogeography of smallmouth bass (Micropterus dolomieu) and comparative myology of the black bass
(Micropterus, Centrarchidae). Ph.D. dissertation, Department of Biological, Geological and Environmental Sciences, Cleveland State University, Cleveland, Ohio.

Borden, W.C., and Stepien, C.A. 2006. Discordant population genetic structuring of smallmouth bass, Micropterus dolomieu Lacepède, in Lake Erie based on mitochondrial DNA sequences and nuclear DNA microsatellites. J. Great Lakes Res. 32(2): 242 257. doi:10.3394/0380-1330(2006)32[242:DPGSOS]2.0.CO;2. 